\title{
Effectiveness of Radiofrequency Ablation Therapy in Osteoid Osteoma: Our 5 Years Experience
}

\section{Radyofrekans Ablasyon Tedavisinin Osteoid Osteomadaki Etkinliği: 5 Yıllık Tecrübemiz}

\author{
(D) Temel Fatih YILMAZ
}

Bezmialem Vakıf University Faculty of Medicine, Department of Radiology, İstanbul, Turkey

\section{ABSTRACT}

Objective: To evaluate the results of treatment with computed tomography (CT) guided percutaneous radiofrequency ablation (RFA) for osteoid osteomas (OO) and to evaluate imaging findings.

Methods: Sixty-three patients (18 female, 45 male) with OO included. Patients were diagnosed by clinic and radiologic findings. Mean age was 18.2 (4-51). Ablation was performed under sedoanalgesia and local anestesia in CT room. Eleven-fifteen gauge coaxial needle was introduced to nidus and 17 gauge RF probe was placed to nidus trough coaxial system. Ablation duration was 6 minutes.

Results: Mean nidus size was measured as $8.3 \mathrm{~mm}(2-16 \mathrm{~mm})$. As a result of statistical analysis, as the size of the nidus increased, the chance of detecting nidus increased on both plain radiography and magnetic resonance imaging $(\mathrm{p}<0.001)$. In 63 patients who underwent RFA, only 3 patients were operated for relapse. One patient received RFA for the second time because of recurrence. Our primary success rate in the treatment of osteoid osteoma was $93.6 \%$ (59/63) and overall success rate was $95.4 \%$.

Conclusion: RFA is a minimally invasive, safe and effective treatment option and has many advantages in the treatment of osteoid osteoma. RFA should be the method of choice for the treatment of osteoid osteoma.

Keywords: Radiofrequency ablation, osteoid osteoma, MRG, nidus

\section{ÖZ}

Amaç: Osteoid osteomlar (OO) için bilgisayarlı tomografi (BT) eşliğinde perkütan radyofrekans ablasyon (RFA) ile tedavi sonuçlarını değerlendirmek ve görüntüleme bulgularını değerlendirmek.

Yöntemler: OO tanısı olan 63 hasta (18 kadın, 45 erkek) çalışmaya dahil edildi. Hastalara klinik ve radyolojik bulgular ile tanı konuldu. Yaş ortalaması 18,2 (4-51) idi. BT odasında sedoanaljezi ve lokal anestezi altında ablasyon yapıldı. On bir-on beş gauge koaksiyel iğne nidusa yerleştirildi. Koaksiyel sistem içerisinden 17 gauge RF probu lezyona ulaştırıldı. Ablasyon süresi 6 dakika idi.

Bulgular: Ortalama nidus boyutu 8,3 mm (2-16 mm) olarak ölçüldü. İstatistiksel analiz sonucunda, nidusun boyutu arttıkça, hem düz radyografi hem de manyetik rezonans görüntülemede nidus saptama şansı artmıştır ( $\mathrm{p}<0,001)$. RFA uygulanan 63 hastada sadece 3 hasta nüks için opere edildi. Bir hasta rekürrens nedeniyle ikinci kez RFA aldı. Osteoid osteoma tedavisinde primer başarı oranımız \%93,6 (59/63) ve genel başarı oranımız \%95,4 idi.

Sonuç: RFA minimal invaziv, güvenli ve etkili bir tedavi seçeneğidir ve osteoid osteomanın tedavisinde birçok avantaja sahiptir. RFA, osteoid osteomanın tedavisi için tercih edilen yöntem olmalıdır.

Anahtar Sözcükler: Radyofrekans ablasyon, osteoid osteoma, MRI, nidus
Address for Correspondence: Temel Fatih YILMAZ, Bezmialem Vakıf University Faculty of Medicine, Department of Radiology, İstanbul, Turkey

E-mail: temelfatihyilmaz@gmail.com ORCID ID: orcid.org/0000-0002-3752-8234
Received: 17.01 .2020

Accepted: 14.05 .2020

Cite this article as: Yılmaz TF. Effectiveness of Radiofrequency Ablation Therapy in Osteoid Osteoma: Our 5 Years Experience. Bezmialem Science 2021;9(2):148-52. 


\section{Introduction}

Osteoid osteoma (OO), first described by Jaffe in 1935, accounts for $10 \%$ of all benign bone tumors. $\mathrm{OO}$ is a benign osteoblastic lesion characterized by an osteoid tissue nidus. $\mathrm{OO}$ is seen in children and young adults (1).

The most important clinical symptom is pain that is more severe at night and responds well to salicylates or other nonsteroidal anti-inflammatory drugs. This is due to the secretion of different amounts of prostaglandins at the tumor side (1).

There are basically three different approaches to treatment. These are surgery, conservative treatment and percutaneous ablation therapy.

Traditional surgical treatment can be very difficult for both the patient and the surgeon. It can be difficult to recognize the tumor during surgery, and incomplete removal can lead to recurrence. Resection of the weight-bearing bone may limit activities for a long time (2).

Approximately 3 years after the onset of symptoms, invasive treatment becomes a necessity in the majority of patients receiving drug therapy. The reason for this is intolerance and side effects that develop as a result of long-term use of drugs. Surgical excision was the preferred method of treatment in the past, and less invasive techniques were developed due to difficult access, risk of complications and long-term postoperative recovery.

Recently, computed tomography (CT)-guided percutaneous radiofrequency ablation (RFA) treatment has become the most frequently used treatment option (3). In this article, we will report the imaging findings of $\mathrm{OO}$ and the results of RFA treatment performed in patients with $\mathrm{OO}$ in our center.

\section{Methods}

\section{Patient Selection}

Sixty three patients who received percutaneous RFA treatment in our interventional radiology clinic between January 2015 and December 2019 were included in our study. Patients' data were analyzed retrospectively. Ethics committee approval was obtained prior to the study. Before the procedure, informed consent was obtained from the patients who underwent the procedure. The diagnosis of $\mathrm{OO}$ was made in the light of both clinical and radiological findings, and CT imaging was performed in all patients.

Forty five of the patients were male and 18 of them were female. The mean age was 18.2 years (4-51). The nidus measurement of $\mathrm{OO}$ was made by CT and the longest nidus size was measured.

CT scans were available in all patients, and direct radiography and magnetic resonance (MR) imaging could not be obtained in all patients. Fifty of the patients had direct radiography and 54 had MR imaging. Presence of nidus and periost reaction with existing imaging modalities were evaluated. Histopathological verfication was not applied to the patients before processing, and the diagnosis was made in the light of clinical and radiological findings.

\section{Procedure}

The procedure was performed by two interventional radiologists with 15 years and 8 years of experience in the CT room. The procedure was performed under sedoanalgesia under the supervision of an anesthesiologist, and the patients' complete blood count and coagulation parameters were checked before the procedure.

The intervention was made in the shortest and easiest way to provide the stability of the coaxial system to the lesion, away from vascular and neural structures. After aseptic cleaning and dressing, 3 to $5 \mathrm{cc}$ of local anesthetic agent (prilocaine hydrochloride 2\%) was injected into the area to be treated and local anesthesia was applied. With the help of a 11-15 gauge coaxial needlecharged drill, the lesion was reached by passing through the skin, subcutaneous tissue, muscle plans, periosteum and cortex. Meanwhile, in order to show the accuracy of the needle direction, $1 \mathrm{~mm}$ thick multi-slice CT imaging was performed on the lesion area. After deciding the correctness of the localization, 17 Gauge "cooled type" RF probe and RF generator were connected in the coaxial system. Care was taken to place the RF probe in the middle of the nidus ( Figure 1 and 2). Nidus lesions with a long diameter of $7 \mathrm{~mm}$ or below, with a $7 \mathrm{~mm}$ active tip, and lesions with a nidus of up to $12 \mathrm{~mm}$ long, were ablated with a RF probe with $10 \mathrm{~mm}$ active tip. The lesions with a long dimension of more than $12 \mathrm{~mm}$ were entered in their polar parts separately and ablated in two parts. The ablation energy was determined automatically by the generator according to the capacitance of the RF probe, and it usually reached a temperature of 900C. Ablation time was 6 minutes. After ablation, the RF probe and coaxial system were carefully removed so as not to damage the bone structure. After the procedure, our patients were followed up by anesthesiologists in our outpatient service for recovery, and they were hospitalized in the interventional radiology service after the recovery. After the procedure, $15 \mathrm{mg} / \mathrm{kg}$ paracetamol was given to the patients for pain control. The patients were discharged the next day after staying in the hospital for one night. The patients were recommended bed rest for 1 week and activity restriction for 1 month. The patients were called for a control examination 3 months later.

Table 1. Process and imaging results

\begin{tabular}{l|l} 
Number of patients & 63 \\
\hline Male & 45 \\
\hline Female & 18 \\
\hline Nidus visibility & \\
CT & $100 \%$ \\
MR & $77.8 \%$ \\
DG & $54 \%$ \\
\hline Mean age & $18.1(4-51)$ \\
\hline Primary procedure success & $93.6 \%$ \\
\hline Total procedure success & $95.4 \%$ \\
\hline CT: Computed tomography, MR: Magnetic resonance
\end{tabular}




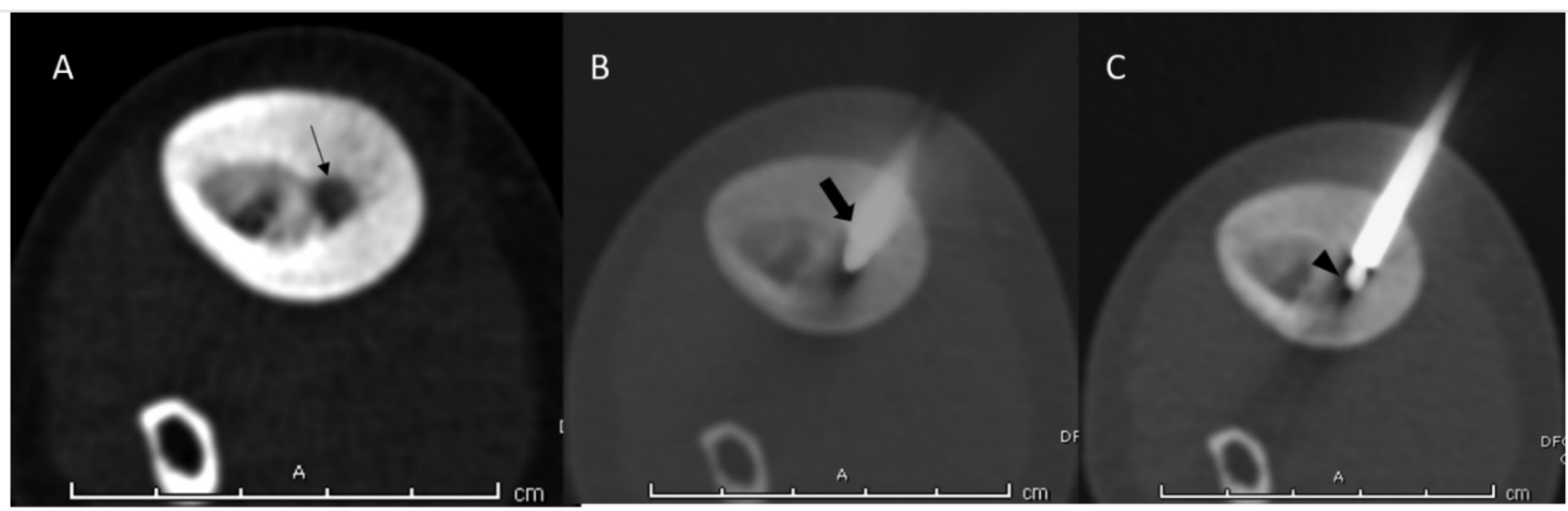

Figure 1 A-C. An 11-year-old male patient was admitted to the orthopedic clinic due to right leg pain that increased at night and continued for 6 months, and an OO lesion with a cortical nidus (black arrow) was found in the right tibial diaphyseal section. The patient underwent CT-guided radiofrequency ablation, and under sedoanalgesia, the 15-gauge coaxial system was placed in the nidus under local anesthesia (thick arrow). The RF probe with a 17 gauge $10 \mathrm{~mm}$ active tip was placed in the nidus through the coaxial system (arrowhead), and the lesion was ablated for 6 minutes at $90 \mathrm{C}$

OO: Osteoid osteoma, CT: Computed tomography

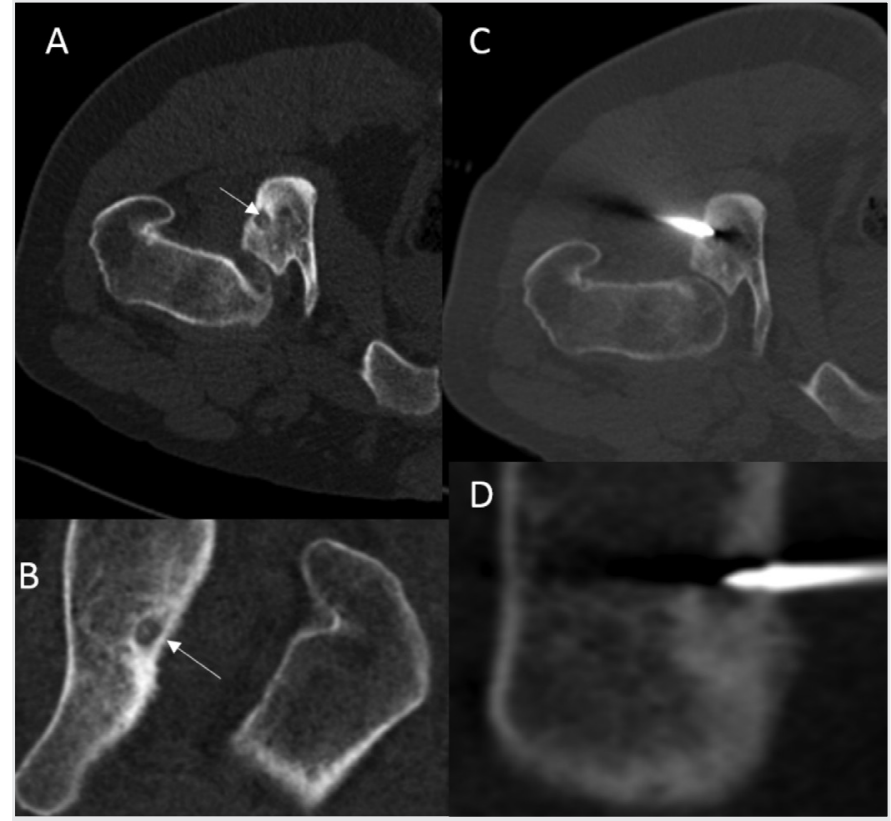

Figure 2A-D. In the examinations of 33-year-old male patient who was admitted with right hip pain, a lesion compatible with an osteoid osteoma with a $7 \mathrm{~mm}$ nidus located in the ischium in the posterior part of the acetabulum in axial (A) and coronal (B) CT sections (arrow). The patient was placed in the prone position and the lesion was entered with a CTguided 11-gauge coaxial needle. Ablation procedure was performed with 17 gauge RFA probe in the coaxial system (C, D)

CT: Computed tomography, RFA: Radiofrequency ablation

\section{Statistical Analysis}

Basic clinical and radiological features of the patients were evaluated with the help of Microsoft Excel program. The relationship between nidus visibility and nidus size in X-ray and MR imaging was evaluated using the Mann-Whitney U test with the help of the SPSS version 20 package program.

\section{Anatomical distribution of lesions}

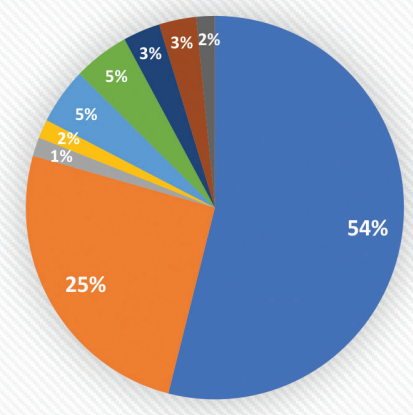

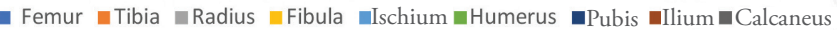

Graphic 1. Anatomical distributions of osteoid osteomas

\section{Results}

Lesion locations were femur in 34 patients (54\%), tibia in 16 patients $(25 \%)$, radius in 1 patient $(1.6 \%)$, fibula in 1 patient $(1.6 \%)$, humerus in 3 patients $(5 \%)$, and ischium in 3 patients (5\%). It was pubis in 2 patients $(3.1 \%)$, iliac bone in 2 patients $(3.1 \%)$, and calcaneus in 1 patient $(1.6 \%)$.

The mean nidus size was measured as $8.3 \mathrm{~mm}(2-16 \mathrm{~mm})$.

As a result of the statistical analysis, as the size of the nidus increased, the chance of detecting nidus on both X-ray and MRI increased $(\mathrm{p}<0.001)$.

Nidus was detected in 27 (54\%) of 50 patients who underwent X-ray. In $28(77.8 \%)$ of 36 patients with periosteal reaction detected by CT imaging, periosteal reaction was detected by $\mathrm{X}$-ray. This rate was calculated as $74 \%$ by MR imaging.

Medullary bone marrow edema was detected in $52(96.3 \%)$ of 54 patients with MRI. Nidus was detected in $42(77.8 \%)$ of 54 patients by MR imaging. 
Nidus was present in all patients with CT. In $57 \%$ of patients with OO, periosteal reaction was found $(36 / 63)$.

In 63 patients who underwent RFA, only 3 patients were operated due to recurrence. One patient received RFA therapy for the second time due to relapse. Our primary success rate in OO treatment was found to be $93.6 \%(59 / 63)$, and our overall success was calculated as $95.4 \%$.

After the procedure, fracture developed in 1 patient after cortical lesion ablation in the femoral neck, and the fracture was fixed with open surgery.

In one patient, RFA probe breakage occurred in a corticomedullary lesion in the distal part of the left femur after the procedure, and removal was achieved by surgery. Our complication rate was found to be $3.2 \%(2 / 63)$.

Our mean follow-up period was calculated as 30.1 months (1-60 months).

\section{Discussion}

Conservative approach, surgical and percutaneous local treatment options are available for treatment of $\mathrm{OO}$ (4). Although $\mathrm{OO}$ is treated with nonsteroidal anti-inflammatory drugs, spontaneous regression can be observed in some patients $(2,5)$. In patients in whom conservative treatment fails, the classical treatment approach is surgery (6). However, in order to completely excise the tumoral tissue with surgical treatment, wide resection can be performed from normal bone tissue, as a result, patients have weakness in the bone structure. Accordingly, prolonged activity restriction, prolonged recovery and increased treatment complications occur (7-9). Surgical complications increase in anatomically difficult parts such as acetabulum, glenoid femoral head and neck (10). RFA is the preferred treatment modality because it significantly reduces the duration of hospital stay and healing time compared to surgery. Success rates with this treatment method have been reported between $70 \%$ and $100 \%$ (11). Chahal et al. (12) reported the primary success rate as $89.7 \%$ in their study. Mahnken et al. (3) reported a success rate of $92 \%$ ( 11 out of 12 patients) after one or two procedures using bipolar RFA. Rosenthal et al. (13) reported a primary success rate of $91 \%$ in a study performed on RFA for OO using monopolar RF ablation (3). In our study, our primary success rate was 93.6\%. Our total success rate was $95.4 \%$.

In our study, we performed RFA treatment with sedoanalgesia and local anesthesia. Some authors recommend treatment under general anesthesia for pain control and position stabilization $(4,5)$. However, we did not have any difficulties in position stabilization and pain control during the procedure. In addition, we did not experience complications due to anesthesia.

Complications such as skin burns, skin and fat necrosis, soft tissue infections, vasomotor instability, tendinitis, and hematoma were reported in previous studies (14-16), and femoral neck fracture developed in 1 patient in our study. Surgical removal was performed in 1 patient due to RF probe breakage. Our complication rate was found to be $3.2 \%(2 / 63)$.

Theoretically, the main disadvantage of this method is that the diagnosis is not histopathologically confirmed. However, some authors argue that the diagnosis is predominantly made clinically and radiologically, that histopathological confirmation is not required, and that its absence does not interfere with the clinical outcome (17). Hoffman et al. concluded that biopsy before treatment was not mandatory because of the considerable amount of false-negative findings in patients with clinically and morphologically uncertain OO. They concluded that 14 (48\%) of 29 patients were diagnosed as having $\mathrm{OO}$ with biopsy (18).

Typical radiographic findings of $\mathrm{OO}$ include cortical nidus with varying degrees of mineralization and cortical thickening, and reactive sclerosis. The nidus is round or oval and usually smaller than $2 \mathrm{~cm}$ (19). Bone density can be reduced due to pain-related use. Although the nidus is very well seen on CT, it appears as an oval or round-shaped hypodense focus. Reactive sclerosis is prominent and can range from mild to large periosteal recession that may obscure the nidus.

Various studies have shown that MR imaging has a limited value in showing the nidus compared to CT (20). In our study, while the nidus was detected at a frequency of $100 \%$ with CT, this rate remained at $77.8 \%$ with MRI. With X-ray, this rate remained at $54 \%$.

Small niduses may not be detected with MRI. In our study, a statistically significant positive correlation was found between the increase in nidus size and visibility of nidus with MRI.

CT emerges as the best imaging method that can be chosen to show the nidus. In particular, multiplanar imaging can show nidus in all patients (20). In our study, the nidus was visible in all 63 patients. Recent studies have reported that the diagnostic value of MR imaging has increased, especially in $\mathrm{OO}$ with medullary localization. In our study, medullary $\mathrm{OO}$ was present in 1 patient. Its nidus was detected after it was diagnosed with MRI. In addition, bone marrow and soft tissue edema, joint effusion, and synovitis are better demonstrated in MR imaging than CT. In our study, bone marrow was detected at a frequency of $96.3 \%$ in patients with $\mathrm{OO}(21-25)$.

\section{Study Limitations}

The small number of our patients, lack of standardization of X-ray, CT and MRI images of the patients referred to our center for treatment from an external center are not standardized, and therefore, the inability to obtain homogeneous imaging findings were among the limitations of our study.

\section{Conclusion}

In conclusion, RFA is a minimally invasive, safe and effective treatment option with low complication rate, and has many advantages in the treatment of OO. For these reasons, RFA should be the method of choice for the treatment of OO. 


\section{Ethics}

Ethics Committee Approval: Approval was obtained from Bezmialem Vakıf University Non-interventional Research Ethics Committee (date: 16.02.2021).

Informed Consent: Retrospective study.

Peer-review: Externally peer reviewed.

Financial Disclosure: The author declared that this study received no financial support.

\section{References}

1. Çakar M, Esenyel CZ, Seyran M, Tekin AÇ, Adaş M, Bayraktar MK, Coşkun Ü. Osteoid osteoma treated with radiofrequency ablation. Adv Orthop 2015;2015:807274.

2. Rosenthal DI, Hornicek FJ, Torriani M, Gebhardt MC, Mankin HJ. Osteoid osteoma: percutaneous treatment with radiofrequency energy. Radiology 2003;229:171-5.

3. Mahnken AH, Tacke JA, Wildberger JE, Günther RW. Radiofrequency ablation of osteoid osteoma: initial results with a bipolar ablation device. J Vasc Interv Radiol 2006;17:1465-70.

4. Yip PS, Lam YL, Chan MK, Shu JS, Lai KC, So YC. Computed tomography-guided percutaneous radiofrequency ablation of osteoid osteoma: local experience. Hong Kong Med J 2006;12:305-9.

5. Simm RJ. The natural history of osteoid osteoma. Aust N Z J Surg 1975;45:412-5.

6. Kneisl JS, Simon MA. Medical management compared with operative treatment for osteoid-osteoma. J Bone Joint Surg Am 1992;74:17985.

7. Sung KS, Seo JG, Shim JS, Lee YS. Computed-tomography-guided percutaneous radiofrequency thermoablation for the treatment of osteoid osteoma-2 to 5 years follow-up. Int Orthop 2009;33:215-8.

8. Jankharia B, Burute N. Percutaneous radiofrequency ablation for osteoid osteoma: How we do it. Indian J Radiol Imaging 2009;19:3642.

9. Kjar RA, Powell GJ, Schilcht SM, Smith PJ, Slavin J, Choong PF. Percutaneous radiofrequency ablation for osteoid osteoma: experience with a new treatment. Med J Aust 2006;184:563-5.

10. Venbrux AC, Montague BJ, Murphy KP, Bobonis LA, Washington $\mathrm{SB}$, Soltes AP, et al. Image-guided percutaneous radiofrequency ablation for osteoid osteomas. J Vasc Interv Radiol 2003;14:375-80.

11. Papathanassiou ZG, Megas P, Petsas T, Papachristou DJ, Nilas J, Siablis D. Osteoid osteoma: diagnosis and treatment. Orthopedics 2008;31:1118.
12. Chahal A, Rajalakshmi P, Khan SA, Rastogi S, Srivastava DN, Gamanagatti S. CT-guided percutaneous radiofrequency ablation of osteoid osteoma: Our experience in 87 patients. Indian J Radiol Imaging 2017;27:207-15.

13. Rosenthal DI, Hornicek FJ, Torriani M, Gebhardt MC, Mankin HJ. Osteoid osteoma: percutaneous treatment with radiofrequency energy. Radiology 2003;229:171-5.

14. Lindner NJ, Ozaki T, Roedl R, Gosheger G, Winkelmann W, Wörtler $\mathrm{K}$. Percutaneous radiofrequency ablation in osteoid osteoma. J Bone Joint Surg Br 2001;83:391-6.

15. Martel J, Bueno A, Ortiz E. Percutaneous radiofrequency treatment of osteoid osteoma using cool-tip electrodes. Eur J Radiol 2005;56:4038.

16. Tillotson CL, Rosenberg AE, Rosenthal DI. Controlled thermal injury of bone. Report of a percutaneous technique using radiofrequency electrode and generator. Invest Radiol 1989;24:888-92.

17. Endo RR, Gama NF, Nakagawa SA, Tyng CJ, Chung WT, Pinto FFE. Osteoid osteoma - radiofrequency ablation treatment guided by computed tomography: a case series. Rev Bras Ortop 2017;52:33743.

18. Hoffmann RT, Jakobs TF, Kubisch CH, Trumm CG, Weber C, Duerr HR, et al. Radiofrequency ablation in the treatment of osteoid osteoma-5-year experience. Eur J Radiol 2010;73:374-9.

19. Papathanassiou ZG, Megas P, Petsas T, Papachristou DJ, Nilas J, Siablis D. Osteoid osteoma: diagnosis and treatment. Orthopedics 2008;31:1118.

20. Swee RG, McLeod RA, Beabout JW. Osteoid osteoma. Detection, diagnosis, and localization. Radiology 1979;130:117-23.

21. Gamba JL, Martinez S, Apple J, Harrelson JM, Nunley JA. Computed tomography of axial skeletal osteoid osteomas. AJR Am J Roentgenol 1984;142:769-72.

22. Levine E, Neff JR. Dynamic computed tomography scanning of benign bone lesions: preliminary results. Skeletal Radiol 1983;9:23845.

23. Glass RB, Poznanski AK, Fisher MR, Shkolnik A, Dias L. MR imaging of osteoid osteoma. J Comput Assist Tomogr 1986;10:10657.

24. Liu PT, Chivers FS, Roberts CC, Schultz CJ, Beauchamp CP. Imaging of osteoid osteoma with dynamic gadolinium-enhanced $\mathrm{MR}$ imaging. Radiology 2003;227:691-700.

25. Davies M, Cassar-Pullicino VN, Davies AM, McCall IW, Tyrrell PN. The diagnostic accuracy of MR imaging in osteoid osteoma. Skeletal Radiol 2002;31:559-69. 